\title{
HOT ROLL BONDING OF ALUMINUM FLAT COMPOSITE MATERIAL WITH STEEL MESH INLAYS
}

\author{
Гараніч Ю.Ю., Фролов Я.В., Гридін О.Ю., Фосвінкель Д., Бояркін В.В., Ремез О.А.
}

\section{ЗВАРЮВАННЯ ГОРЯЧОЮ ПАКЕТНОЮ ПРОКАТКОЮ ПЛАСКОГО КОМПОЗИЦЙНОГО МАТЕРІАЛУ ЗІ СТАЛЬНИМИ СІТЧАСТИМИ ВСТАВКАМИ}

\begin{abstract}
A flat roll bonded composite material based on aluminum matrix and reinforcing steel mesh inlets can be applied in aerospace, automotive, train, ship building, and household industries. However, the development of its manufacturing technology requires complete understanding of transformation of its components during the roll bonding process as well as an impact of technological parameters on its bonding quality. Thus, bonding properties between aluminum clad layers AA6060 and steel meshed reinforcement inlets AISI 304 (expanded sheet) and ASISI 321 (wire mesh) of roll-bonded reinforced composite have been investigated in this study. The applied reduction was 30 and $20 \%$, the temperature of the roll bonding process was 500 and $400^{\circ} \mathrm{C}$, the temperature of the heat treatment process was $520^{\circ} \mathrm{C}$ with holding time 45 minutes.

During the peel test, the destruction of inlets was observed in all cases, therefore, no data were obtained regarding the correlation between the reduction magnitude and the peel strength. At the same time, the effect of temperature and heat treatment on the bonding strength between layers have been studied by means of peel test.

In addition, a simulation of the hot roll bonding process of aluminum with expanded mesh inlets was developed using the finite element method (FEM) via QForm software. Conditions of FEM simulation corresponded to experimental ones and the simulation was verified with the experiment by the comparison of deformation parameters of whole composites and angles between strands during the opening of expanded mesh cells.

Key words: roll bonding, composite material, aluminum, steel, mesh
\end{abstract}

\begin{abstract}
Плаский композиційний матеріал на основі алюмінієвої матриці та армувальної сталевої сітки що виготовлений шляхом гарячої пакетної прокатки може використовуватись в аерокосмічній, автомобільній, залізничній, суднобудівній та побутовій промисловості. Однак, розроблення технології виготовлення такого композиційного матеріалу вимагає повного розуміння характеру пластичної течії його складових під час процесу пакетної, а також впливу технологічних параметрів процесу пакетної прокатки на його якість зчеплення між шарами композиту. Таким чином, в даній роботі було досліджено властивості зчеплення між шарами алюмінієвого сплаву марки АДЗ1 та сталевими армувальними сітчастими вставками на основі сталей марок 08X18H10 (просічно-витяжна сітка) $i$ Х18H0T (плетена сітка) композиційного матеріалу. Степінь відносного обтиснення під час пакетної прокатки становив 30 і 20\%, прокатка відбувалася при температурі 500 і $400{ }^{\circ} \mathrm{C}$, при цьому температура процесу термічної обробки склала $520{ }^{\circ} \mathrm{C}$, а час витримки - 45 хвилин.

При випробуванні на розшарування зразків у всіх випадках спостерігалося руйнування вставок, тому не отримано даних щодо кореляції між ступенем обтиснення і силою відшарування. При цьому, було досліджено вплив температури та наявності термічної обробки на міцність зв'язування між шарами за допомогою випробовування на розшарування.

Крім того, було розроблено моделювання процесу гарячої пакетної прокатки алюмінію з вставками із просічновитяжної сітки з використанням методу скінченних елементів за допомогою програмного забезпечення QForm. Умови процесу моделювання відповідали експериментальним, при цьому апробація моделювання було була проведена шляхом порівняння параметрів деформації композиційних матеріалів і кутів між нитками під час розкриття вставки на основі просічно-витяжної сітки.

Ключові слова: пакетна прокатка, композиційний матеріал, алюміній, сталь, сітка
\end{abstract}

Introduction. Roll bonding is widely used for manufacturing of flat layered metal composites. In this research it is investigated the process of manufacturing of layered composite material that consists of aluminum

Гараніч Юрій Юрійович - аспірант НМетАУ, Фролов Ярослав Вікторович - д.т.н, проф. НМетАУ,

Гридін Олександр Юрійович - д.т.н., університет Падерборну (ФРН); Дітріх Фосвінкель - н.с. університету Падерборну (ФРН);

Бояркін Вячеслав Володимирович - к.т.Н., НМетАУ,

Ремез Олег Анатолійович - к.т.н, НМетАУ. layers and reinforced with meshed austenitic steel inlets. One of the most important quality criterion of a product made by this process is the strength of bonding between layers, since it determines an opportunity to 
apply a product in engineering fields.

Utilizing of inner layers made of stainless steel may be a promising way to enhance not only the strength of the composite material itself but also its bonding strength. Thus, aluminum reinforced with steel may allow broadening the use of aluminum in aerospace, automotive, shipbuilding and household industries, decreasing of specific weight of structural parts and, hence, minimization of fuel consumption. Thus, in this study it is proposed to apply steel mesh materials as reinforcement inserts, this might help to decrease specific weight comparing to a solid steel sheet, in addition, it is interesting to study the effect of aluminum flowing into mesh cells on the bonding strength, since the perimeter of bonding increases. Moreover, in this case bonding appears not only between horizontal surfaces of metals but also between surfaces inside meshed cells, thus, it provides new spatial orientation of bonding between layers.

Purpose of the research. The target of this research is to study the impact of roll bonding parameters on the bonding quality and clarify a character of plastic deformation of the composite compounds.

Analysis of publications. Numerous researches have clarified the influence on the bonding strength of such main parameters of the roll bonding process as a reduction [1-13], a temperature [1,2,4,6-10,14,15], a heat treatment process $[2,6,8,10,14,17,19]$, a surface treatment $[4,19,20]$, a rolling speed $[5,10,20]$, it was also studied the effect of asymmetrical rolling on bonding strength $[17,21]$. Researchers $[5,8]$, who studied the roll boning process of aluminum clad sheets 1050, 1100 and medium carbon steel have found that in case of cold roll bonding the threshold of deformation for achieving bonding between layers is around $10 \%$. The same result is described in the work [6], where aluminum clad sheets 1050 and austenitic steel were roll bonded. This is considerably lower than that of roll bonded simple aluminum sheets 1100/1100 with reduction threshold $30 \%[6,10]$. And in the research [6] 38\% was enough to achieve bonding strength equaled to strength of aluminum clad layers and austenitic steel inner layer.

There are studies of reinforcing of aluminum solid sheet material with steel wire mesh by means of roll

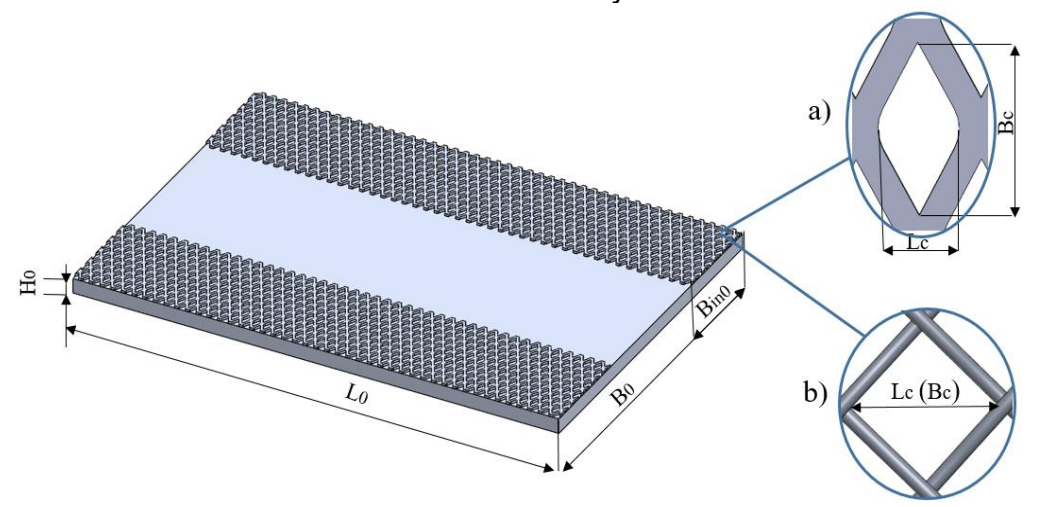

Figure 1 - Scheme of half composite with steel meshed inlets ( $a$ - expanded sheet; $b$ - wire mesh) bonding [22-24] and twin-roll casting [25]. However, the researchers were focused on enhancing of the tensile strength and the effect of such inlet on the bonding strength is unrevealed. Nevertheless, it is reported that there is a high concentration of stress at the its manufacturing technology due to the combination of the longitudinal strain while the rolling process and intensive compression due to the wire overlaying which can result in destruction of steel wire in this region. In that way wire mesh constrains reduction that can be applied to the composite as well as it limits an opportunity to perform further operations such as stamping, bending, etcetera.

According to works [22-25], technologically, wire mesh should be oriented with $45^{\circ}$ to the rolling axis, this direction provides the best plasticity of the composite, since cell of the steel wire mesh have an opportunity to lengthen due to rotation of wires at the zones of intersection. In addition, in the works [24,25] it is shown that zones of complicated penetration of metal appear near the overlaying of wires resulting in voids in this zones and, consequently, in decreasing of bonding strength. Thus, the presence of knots in wire mesh is rather a disadvantage in condition of roll bonding, therefore, it was decided to apply also an expanded steel sheet material as a reinforcement inlet for the roll bonded composite.

Experimental procedure. Specimens consisted of two layers of aluminum alloy AA6060 and two meshed steel inserts located at the edges of aluminum strips. Constituents workpieces were degreased via alcohol, fastened with four rivets at forward and backward ends, preheated and hot roll bonded under conditions represented in table 1 . The steel inlets were installed between aluminum layers around the edges as it is shown in the figure 1. Two types of inlets were utilized: wire mesh inlet made of austenitic steel AISI 321 and expanded sheet inlet made of austenitic steel AISI 304, in addition, specimens without inlets were used as reference ones. The specification of the initial geometry of the composite and parameters of the process are presented in the table 1 . Roll bonding of each composite was performed per one rolling pass. 
Table 1 - Condition of the roll bonding process

Parameter
Aluminum layer thickness, $\mathrm{mm}$

Aluminum layer width, $\mathrm{mm}$

Aluminum layer/steel inlet length, $\mathrm{mm}$

Steel inlet thickness (exp. sheet/wire), mm

Expanded sheet cell parameters: $L_{c} \times B_{c}, m m$

Wire mesh cell parameters: $L_{c} \times B_{c}, m m$

Angle between strands, exp. sheet, ${ }^{\circ}$

Angle between strands, wire mesh, ${ }^{\circ}$

Steel inlet width (exp. sheet/wire), $\mathrm{mm}$

Gap between inlets, $\mathrm{mm}$

Working roll diameter, $\mathrm{mm}$

Temperature, ${ }^{\circ} \mathrm{C}$

Reduction, \%

Rolling speed, $\mathrm{mm} / \mathrm{sec}$

A part of specimens was exposed to annealing after roll bonding in order to investigate the effect of heat treatment on bonding properties. The specimens were held up for $45 \mathrm{~min}$ at $520^{\circ} \mathrm{C}$ degrees. After the all experimental procedures, a peeling test via "MTS Landmark" was performed with parameters shown on the fig. 2. Specimens for testing were taken from the part of strips with reinforcing inlets.

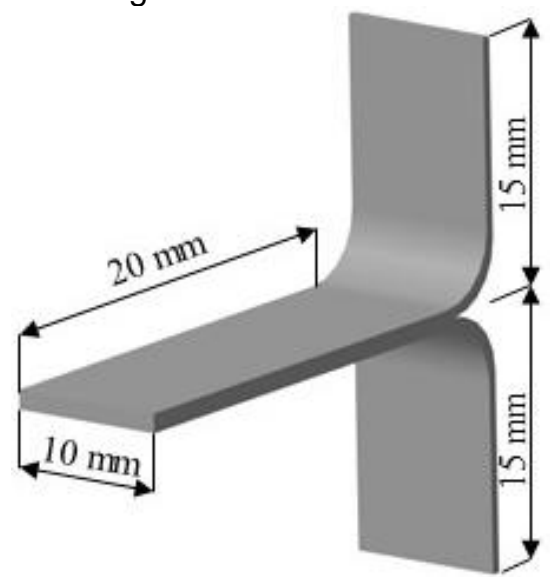

Figure 2 - Schematic illustration of the specimen for peeling test

Simulation procedure. The FEM simulation of the roll bonding process was developed via QForm software. Geometrical parameters and temperature in the simulation correspond to experimental ones; as a model of friction between tools and worpiece the Zilberg's model was applied. Between billets it was set up "Full sticking". This admission suggests existence of initial bonding between elements of worpiece and ab-

Value
3
70
200
0,5
$2 \times 4$
$2 \times 2$
60
90
20
50
135
$400 ; 500$
$20 ; 30$
300

sence of sliding of layers relative to each other. Due to the presence of a plane of symmetry, only half of the process was simulated as it can be seen in figure. 3 The presence of curvatures in the finite element model of expanded sheet inlet was neglected.

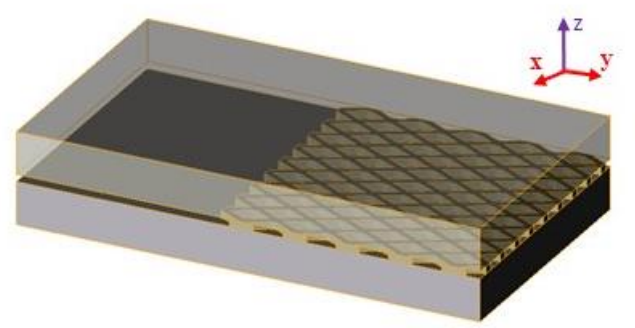

Figure 3 - Finite element model of the initial workpiece in QForm cut off in the plane of symmetry

The flow stress curves of aluminum alloy 6060 was taken from the study [26]. The flow stress of steel inlets was set via Hansel-Spittel model [27]. With corresponding coefficients that consider initial strain resistance, temperature, strain and strain rate presented in the ta-

ble 2. $\sigma=A_{1} \cdot e^{-m_{1} T} \cdot \varepsilon^{m_{2}} \cdot e^{-m_{4} \varepsilon} \cdot \dot{\varepsilon}^{m_{3}}$. (1)

Where where $A$ is a constant, $m_{1}$ to $m_{8}$ are exponents containing the influence of the deformation conditions on the flow stress. 
Table 2-Coefficients of Hansel-Spittel model for steel AISI 304

\begin{tabular}{lllll}
$\mathbf{A}_{1}$ & $\mathbf{m}_{\mathbf{1}}$ & $\mathbf{m}_{\mathbf{2}}$ & $\mathbf{m}_{\mathbf{3}}$ & $\mathbf{m}_{\mathbf{4}}$ \\
$\mathbf{1 3 3 5 , 3 3 2}$ & -0.00148 & 0,36219 & 0,01014 & 0,003372 \\
\hline
\end{tabular}

Results and discussion. Geometrical parameters and parameters of deformation of the roll bonded composites obtained experimentally and in FEM simulation are presented in the table 3 . It can be seen that parameters of reduction and expanding obtained in simu-

lation have a good agreement compared to experimental ones, however, there is a deviation of elongation parameter obtained in FE model compared to the experimental one.

Table 3-Geometrical parameters of roll bonded specimens

\begin{tabular}{|c|c|c|c|c|c|c|c|c|}
\hline Reduction & $\begin{array}{l}\text { Initial } \\
\text { width, } \\
\text { mm }\end{array}$ & $\begin{array}{l}\quad \text { Initial } \\
\text { length, } \\
\text { mm }\end{array}$ & $\begin{array}{l}\text { Thic } \\
\text { after } \\
\mathrm{mm}\end{array}$ & $\begin{array}{c}\text { kness Width } \\
\text { pass,after } \\
\text { pass, } \\
\text { mm }\end{array}$ & $\begin{array}{l}\text { Length } \\
\text { after pass,ing } \\
\mathrm{mm}\end{array}$ & $\begin{array}{l}\text { Expand- } \\
\text { g, } \\
\%\end{array}$ & $\begin{array}{l}\text { Elongation, } \\
\%\end{array}$ & $\begin{array}{l}\text { Angle } \\
\text { between } \\
\text { strands, } \\
\text { (exp. } \\
\text { sheet) }\end{array}$ \\
\hline \multicolumn{9}{|l|}{ Simulation } \\
\hline $20 \%$ & 70 & 20 & 4,8 & 70,8 & 26 & 1,14 & 30 & 80 \\
\hline $30 \%$ & 70 & 20 & 4,2 & 71,76 & 29,4 & 2,51 & 47 & 90 \\
\hline \multicolumn{9}{|l|}{ Experiment } \\
\hline $20 \%$ & 70 & 200 & 4,8 & 71,5 & 290 & 2,14 & 45 & 86 \\
\hline $30 \%$ & 70 & 200 & 4,2 & 72 & 325 & 2,86 & 62,5 & 90 \\
\hline
\end{tabular}

The effect of technological parameters upon the peel force. The bonding strength is evaluated by means of peel force parameter that is defined during the peeling test. After roll bonding, in all cases a destruction of inner austenitic steel inlets was observed. As a result of such destruction, the analysis of the peel force appeared to be impossible, therefore, is not presented in this study.

On the other hand, the effect of the annealing can be seen by the comparison of the peel force of specimens directly after the roll bonding process and those after the post heat treatment. The effect of the heat treatment is presented in the fig. 10. The list of the roll bonded composites are presented in the table 4.

It can be seen in the diagram on the fig. 5 that almost in all cases bonding strengthening was observed. In two cases (number 2 and 6) the peeling force dropped after the heat treatment.

Since a part of specimens in case of $20 \%$ reduction and expanded sheet inlets or without inlet disbonded unpromptedly, they are not presented in the list. Specimens with wire mesh inlets are presented fully. A number of each couple of specimens in the table corresponds to that one in the diagram. In case of reference specimens, where no inlets were applied specimens after rolling at $400^{\circ} \mathrm{C}$ without the heat treatment and specimens after the rolling at $500^{\circ} \mathrm{C}$ with the heat treatment were compared.

It can be seen that specimens with inlets after heat treatment presented better results than reference ones, thus, meshed steel inlets provide positive effect upon the bonding strength, however further developments of such process is necessary in order to avoid disadvantages obtained in the current stage. Moreover, peel strength of specimens with wire mesh inlet appeared to be higher than that of specimens with expanded metal owing to higher destruction rate of expanded metal compared to wire mesh.

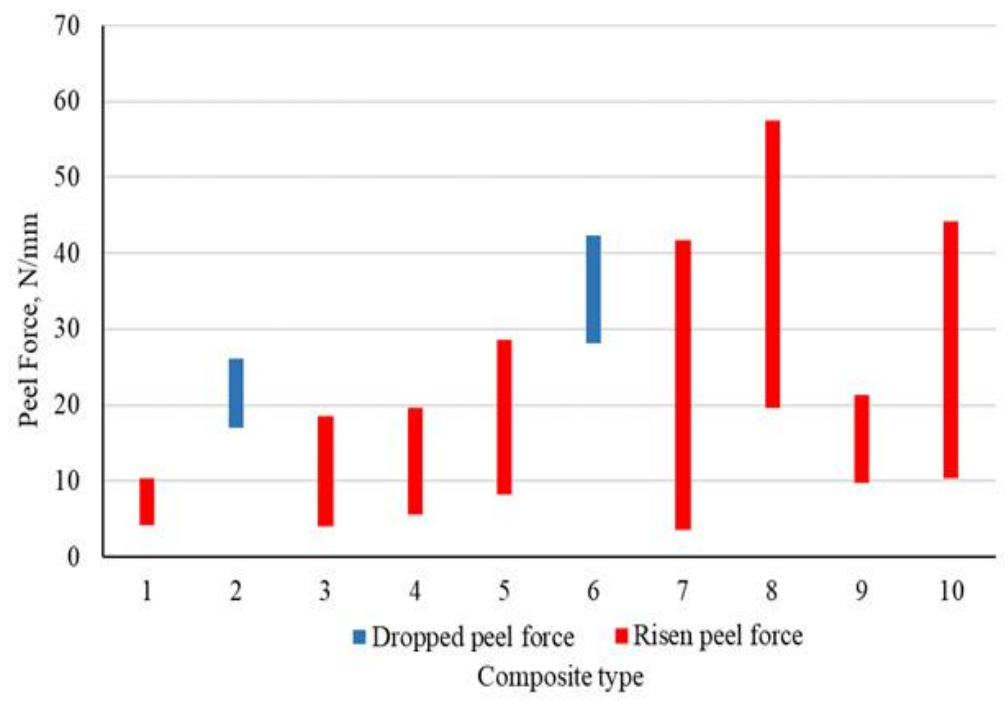

Figure 5-Effect of the heat treatment on the peeling force 
Table 4- couples of specimens for peel tests

\begin{tabular}{llll}
\hline Number & Reduction, $\%$ & Temperature, ${ }^{\circ} \mathrm{C}$ & Type of an inlet \\
$\mathbf{1}$ & 20 & $400 / 500$ & - \\
$\mathbf{2}$ & 30 & 400 & - \\
$\mathbf{3}$ & 30 & 500 & - \\
$\mathbf{4}$ & 20 & 500 & Expanded sheet \\
$\mathbf{5}$ & 30 & 400 & Expanded sheet \\
$\mathbf{6}$ & 30 & 500 & Expanded sheet \\
$\mathbf{7}$ & 20 & 400 & Wire mesh \\
$\mathbf{8}$ & 20 & 500 & Wire mesh \\
$\mathbf{9}$ & 30 & 400 & Wire mesh \\
$\mathbf{1 0}$ & 30 & 500 & Wire mesh \\
\hline
\end{tabular}

Conclusions. Due to uncontrolled destruction of steel inlets the studying of the dependence of peel force upon the reduction appeared to be impossible. At the same time, the effect of heat treatment on its magnitude appeared to be positive in almost all cases except of two observations. At the same time, heat treatment allowed an increase of peel force up to 35 $\mathrm{N} / \mathrm{mm}$.

It can be seen that the specimens with wire mesh inlets provided higher magnitude of peel force compared to specimens with expanded mesh inlets and those without any inlet. The possible reason of that is higher rate of destruction of expanded metal. Howev- er, high level of fluctuation of obtained results is observed.

Developed FE simulation via QForm software has shown an agreement with experimental results. There is a deviation of elongation magnitude that can be explained by common immersion of finite element mesh into one another. However, the simulation presented very similar results of expanded mesh cells opening.

The possible reason of destruction of expanded sheet inlets is their work hardening due to their manufacturing procedure. This will be clarified in future studying. At the same time, the destruction of wire mesh inlets is expected, since it is explained by previous researchers [22-25].

\section{REFERENCES}

1. Eizadjou M. Investigation of roll bonding between aluminum alloy strips / M. Eizadjou, H. Danesh Manesh, K. Janghorban. // Materials and Design. - 2008. - №29. - C. 909-913.

2. Investigation on bonding strength of steel/aluminum clad sheet processed by horizontal twin-roll casting, annealing and cold rolling / [G. Chen, J. Li, H. Yu et al.]. // Materials and Design. - 2016. - №112. - C. 263-274.

3. Proposal of bond criterion for hot roll bonding and its application / [X. Zhang, T. Yang, S. Castagne et al. // Materials and Design. - 2011. - №32. - C. 2239-2245.

4. Eizadjou M. Mechanism of warm and cold roll bonding of aluminum alloy strips / M. Eizadjou, H. Danesh Manesh, K. Janghorban. // Materials and Design. - 2009. - №30. - C. 4156-4161.

5. Danesh Manesh H. Effective parameters on bonding strength of roll bonded Al/St/Al multilayer strips / $\mathrm{H}$. Danesh Manesh, H. Shahabi. // Journal of Alloys and Compounds. - 2009. - №476. - C. 292-299.

6. Akramifard H. Cladding of Aluminum on AISI 304L Stainless Steels by Cold Roll Bonding: Mechanism, Microstructure, and Mechanical Properties [Electronic resource] / H. Akramifard, H. Mirzadeh, M. Parsa // Materials Science and Engineering. - 2014. - mode of access: http://dx.doi.org/10.1016/j.msea.2014.06.109.

7. Development of Nonferrous Clad Plate and Sheet Rolling by Warm Rolling with Different Temperature of Materials / A. Yahiro, T. Masui, T. Yoshida, D. Doi. // 6. - 1991. - №31. - C. 647-654.

8. Danesh Manesh $\mathrm{H}$. The effect of annealing treatment on mechanical properties of aluminum clad steel sheet / H. Danesh Manesh, A. Karimi Taheri. // Materials and Design. - 2003. - №24 - C. 617-622.

9. Sandwich rolling of twin-roll cast aluminium-steel clad strips / [M. Stolbchenko, O. Grydin, F. Nürnberger et al.]. // Procedia Engineering. - 2014. - №81. - C. 1541-1546. [10] Roohollah R. Investigation of the parameters of the cold roll bonding (CRB) process / R. Roohollah, M. Toroghinejad. // Materials Science and Engineering. - 2010. - №527. - C. 2320-2326.

11. Chaudhari G. Cold roll bonding of multi-layered bi-metal laminate composites / G. Chaudhari, V. Acoff. // Composites Science and Technology. - 2009. - №69. - C. 1667-1675.

12. Abbasi M. Effects of processing parameters on the bond strength of $\mathrm{Cu} / \mathrm{Cu}$ roll-bonded strips / M. Abbasi, M. Toroghinejad. // Journal of Materials Processing Technology. - 2010. - №210. - C. 560563. 
13. Haranich Y. Y. Comprehensive analysis of metal-polymer sandwich composite manufacturing / Y. Y. Haranich, Y. Y. Frolov. // Material working by pressure. - 2017. - №2. - C. 2017.

14. Yan H. A study of warm and cold roll-bonding of an aluminium alloy / H. Yan, G. Lenard. // Materials Science and Engineering. - 2004. - №385. - C. 419-428.

15. Peng $X$. Effect of rolling temperature on interface and bond strength development of roll bonded copper/aluminium metal laminates / X. Peng, G. Heness, W. Yeung. // Journal of Materials Science. 1999. - №34. - C. 277-281.

16. Mechanical properties of the aluminum roll-bond laminate AA5005-AA5083-AA5005 / [A. Weck, P. B?saillon, L. Nong et al.]. // Materials Science and Engineering. - 2011. - №528. - C. 6186-6193.

17. Pan D. Cold roll bonding of bimetallic sheets and strips / D. Pan, K. Gao, Y. Yu. // Materials Science and Technology. - 1989. - №5. - C. 934-939.

18. Effect of heat treatment on bond characteristics of aluminium clad steel: Production and characteristics of vacuum roll bonded clad materials / [S. Mukae, K. Nishio, M. Kato et al.]. // Journal of the Japan Welding Society. - 1995. - №12. - C. 528-533.

19. Investigation of different parameters on roll bonding quality of aluminium and steel sheets [Electronic resource] / [M. Buchner, B. Buchner, B. Buchmayr et al.] // International Journal of Material Forming. 2008. - mode of access: DOI 10.1007/s12289-008-0136-7.

20. Macro- and micro-surface engineering to improve hot roll bonding of aluminum plate and sheet / [J. Liu, S. Sheu, M. Karabin et al.]. // Materials Science and Engineering. - 2008. - №479. - C. 45-57. [21] 032 AN EXPERIMENTAL STUDY OF THE EFFECT OF ROLL-SPEED

22. Roll Bonding of Steel Net-Reinforced Aluminium Strips [Electronic resource] / [M. Stolbchenko, H. Makeieva, O. Grydin et al.] // Materials Research. - 2017. - mode of access: DOI: http://dx.doi.org/10.1590/1980-5373-MR-2017-0941.

23. Strain parameters at hot rolling of aluminum strips reinforced with steel netting [Electronic resource] / [M. Stolbchenko, H. Makeieva, O. Grydin et al.] // Journal of Sandwich Structures \& Materials. - 2018. mode of access: DOI: 10.1177/1099636218792539.

24. Influence of strain parameters at rolling on the properties of wire-reinforced aluminium composites [Electronic resource] / [Y. Frolov, M. Stolbchenko, O. Grydin et al.] // International Journal of Material Forming. - 2018. - mode of access: https://doi.org/10.1007/s12289-018-1431-6.

25. Huang $\mathrm{H}$. Mechanical properties and reinforced mechanism of the stainless steel wire mesh-reinforced Al-matrix composite plate fabricated by twin-roll casting [Electronic resource] / H. Huang, J. Wang, W. Liu // Advances in Mechanical Engineering. - 2017. - mode of access: DOI: 10.1177/1687814017716639.

26. Industrial Benchmark 2015: process monitoring and analysis of hollow EN AW-6063 extruded profile / [A. Gamberoni, L. Donatia, B. Reggiani et al.]. // Aluminium Two Thousand World Congress and International Conference on Extrusion and Benchmark ICEB 2015. - 2015. - №2. - C. 4714-4725.

27. Spittel M. Numerical Data and Functional Relationships in Science and Technology / M. Spittel, T. Sittel. - Kempten: AZ-Druck, 2009. - 993 c. - (Springer). - (Mateials; т. 2).

Стаття поступила 1.11.2018 